\title{
Inappropriateness of prostate cancer screening by PSA in young Algerian farmers ${ }^{*}$
}

\author{
Abdelkrim Berroukche ${ }^{1,2 \#}$, Malika Bendahmane-Salmi ${ }^{1,3}$, Badreddine Abdelkrim Kandouci $^{1}$ \\ ${ }^{1}$ Research Laboratory of Environment and Health (RLEH), Faculty of Medicine, University Hospital, Sidi-Bel-Abbes, Algeria; \\ ${ }^{\#}$ Corresponding Author: kerroum1967@yahoo.fr \\ ${ }^{2}$ Department of Biology, Faculty of Sciences and Technology, Moulay Tahar University, Saida, Algeria \\ ${ }^{3}$ Department of Biology, Faculty of Sciences, Djillali Liabes University, Sidi-Bel-Abbes, Algeria
}

Received 23 May 2013; revised 24 June 2013; accepted 23 July 2013

Copyright (C) 2013 Abdelkrim Berroukche et al. This is an open access article distributed under the Creative Commons Attribution License, which permits unrestricted use, distribution, and reproduction in any medium, provided the original work is properly cited.

\begin{abstract}
Introduction: It is not yet established, in Algeria, a consensus on the use of prostate specific antigen (PSA) for the screening of prostate cancer (PCA) while some doctors speculate and recommend a serum-PSA assay to the young men. The objective is to assess the prevalence of PSA by age in young farmers. Methods: This study was undergone on $\mathbf{4 0 3}$ farmers, exposed to the risk of pesticides, aged between $30-70$ years and living in rural areas of Saida (Western Algeria), during the period 2006 to 2012. The values of the PSA were collected during PCA screening and compared by statistical tests that revealed significant difference. Results: It was found that $15.6 \%$ of patients were under the age of 40 years. The total PSA (TPSA) increases with age and varies from 1 to $2 \mathrm{ng} / \mathrm{ml}$ for the respective age groups of $30-39$ and $60-69$ years. Approximately, $16.6 \%$ of men (or $1 / 6$ ), who underwent PSA assay were under the age of 40 years. Conclusion: According to the recommendations of Algerian associations of cancer, men younger than $\mathbf{5 0}$ years may not be candidates for screening by PSA.
\end{abstract}

Keywords: Prostate Specific Antigen; Prostate Cancer; Age; Pesticides

\section{INTRODUCTION}

Data records of Algerian cancers show that incidence

*Conflict of Interest: No conflicts of interest declared. There are no financial and personal relationships with other people or organizations that could unduly influence our work. of prostate cancer (PCA) new cases is on the increase [1]. The aging population coupled with progress of PCA screening may partly explain this increase. The rising of PCA incidence leads to questions about the existence of poorly known risk factors such as environmental or occupational exposures [2]. Farmers are a class of workers with a high risk of developing PCA [2]. The use of pesticides and chemicals in agriculture is widely disputed [3]. Agriculture is one of the fields using more pesticides in Algeria. The interview between the patient and the physician is very important to understand the advantages and disadvantages of PCA screening [4-6,8,9]. According to studies, the PCA screening is usually recommended for men older than 50 years [7] while for groups of men at high-risk such as patients with a family history of PCA, it is recommended to start a screening at age of 45 years $[4,10,11]$. According to data provided by the specialized agencies in Algeria, it is estimated 10 to 14 PCA patients per 100,000 inhabitants demonstrating the extent of this pandemic [1]. However, PCA screening, among men aged less than 50 years, is a matter of debate. Test of serumprostate specific antigen (PSA) enzyme immuno-assay is widely used in Algeria. Although the risk of PCA is higher in farmers, it seems that it is unnecessary to make a PSA screening in men younger than 50 years. The PSA screening, in younger men, could be a risk of over-diagnosis of PCA and a source of false positives. The aim of this study was to assess the prevalence of PSA according to age group in young farmers.

\section{METHODS}

\subsection{Study Population}

Among a total of 510 men, only 403 subjects were the focus of this study. This is a retrospective and descriptive study of farmers older between 30 - 70 years followed 
during the period from January 2006 to March 2012 (ie 6 years). These workers were identified through their registration on the electoral lists available to our research by the statistical department in the town hall of Saida. The patients were reconfirmed at their works and in various institutions they attended such as agricultural cooperatives, agricultural chamber, national office of feed for cattle (NOFC) and farms. The inclusion criteria were informed consent, patients lived in areas of Saida (western Algeria) who underwent a serum-total PSA (TPSA) assay using the same technique (TPSA-VIDAS test, bio Merieux laboratory, France).

\subsection{Data Collection}

All farmers showed pathological history (diabetes, hypertension, hyperlipidemia and cholesterol) that's reported in their medical records at various specialized departments of Saida hospital. After obtaining formal approval from hospital and a clear consent of patients, analysis of file records was performed which showed the demographic parameters (age, residence, date of birth, marital status and number of children), anthropometric parameters (weight, height and body mass index) and a medical history of patients. During the passage of patients in the various departments of Saida hospital for routine medical control, blood samples were taken to establish both biological tests and serum-TPSA assay.

\subsection{Serum-TPSA Assay}

All patients were evaluated by determination of the TPSA-serum level. Blood samples were collected at the urology department in Saida hospital and taken directly to the laboratory of biological analysis in the same hospital. Approximately $10 \mathrm{ml}$ of blood were collected intravenously in a dry tube. The blood was centrifuged and serum was frozen at $-20^{\circ} \mathrm{C}$ until to be used in the assay. The sera were frozen for a period not exceeding three months and then thawed for achieving TPSA assay knowing that for short periods of freezing and TPSA assay is little changed. TPSA assays are undergone in mini VIDAS analyzer (bio-Merieux, France). The used method was the technique of enzyme-linked fluorescent assay (ELFA): it is an enzyme immunoassay ELISA "sandwich" in heterogeneous phase where the molecules of PSA are caught between two monoclonal antibodies of murine nature. Reading results of the TPSA assay is done in two stages to a final detection by fluorimetry. The cut-off of TPSA is $4 \mathrm{ng} / \mathrm{ml}$, prescribed by the kit supplier. The detection limit of this method is $0.07 \mathrm{ng} / \mathrm{ml}$ and the range of the VIDAS-TPSA kit extends to $100 \mathrm{ng} / \mathrm{ml}$. Samples, with concentrations of TPSA over $100 \mathrm{ng} / \mathrm{ml}$, were retested after dilution in sample diluent TPSA (calf serum + sodium azide $0.9 \mathrm{~g} / \mathrm{l})$.

\subsection{Statistical Analysis}

The SPSS version 11.5 software was used in this study for all statistical analyzes. Comparisons of means were carried out by the ANOVA test to reveal significant differences at $\mathrm{p}<0.05$.

\section{RESULTS}

The distribution of age factor according to serumTPSA concentration in patients is presented in Table 1. A rate of $15.6 \%$ of patients were older under 40 . The analysis of mean serum concentrations of TPSA and stratified variance by age were performed.

These results showed that tumor biomarker (or TPSA) increased proportionally with the age factor. The increase of TPSA ranged from $1.1 \mathrm{ng} / \mathrm{ml}$ in the patients older of 30 years to $2.3 \mathrm{ng} / \mathrm{ml}$ in patients older of 60 years.

The TPSA average, among patients older between 60 69 years, was significantly higher than that of patients older between 30 - 39 and 40 - 49 years.

The proportions of patients with serum-TPSA concentrations higher than $4 \mathrm{ng} / \mathrm{ml}$ in the age ranges of $30-39$, $40-49,50-59$ and $60-69$, were respectively $2.1 \%$ (1/63), $1.7 \%$ (3/169), 4.5\% (7/145), 5.8\% (1/17).

\section{DISCUSSION}

Data analysis for serum-TPSA levels, in our series, had revealed that approximately one in 6 farmers was younger than 50 years. It also recorded a low average serum-TPSA for age groups of $30-39$ and 40 - 49 years. For these TPSA values $(1.1$ and $1.2 \mathrm{ng} / \mathrm{ml})$, the risk of developing PCA is minimal. These results can join those of a study undergone in the area of Gazza, between 1990-1999 on a population of 141 Palestinian with PCA, living mainly from agriculture and exposed to risk of pesticides, including $0.7 \%$ (ie $1 / 141$ ) were aged between 25 - 44 years and $10 \%$ (ie 14/141) between 45 - 55 years [12]. While our results were not similar to those of a meta-analysis underwent in different governorates of Brazil (Rio de Janeiro and Porto Alegre) between 19891998. It was found a strong association (Odds $=5.34$ )

Table 1. Mean values and prevalence of PSA among farmers according to age groups.

\begin{tabular}{cccc}
\hline $\begin{array}{c}\text { Age } \\
\text { (years) }\end{array}$ & $\begin{array}{c}\text { Patients } \\
\mathrm{N}(\%)\end{array}$ & $\begin{array}{c}\text { TPSA }(\mathrm{ng} / \mathrm{ml}) \\
\text { Mean }( \pm \mathrm{SD})\end{array}$ & $\begin{array}{c}\text { Frequency }(\%) \\
(\text { TPSA }>4 \mathrm{ng} / \mathrm{ml})\end{array}$ \\
\hline $30-39$ & $63(14.6)$ & $1.1(0.82)^{*}$ & $2.1(1 / 63)$ \\
$40-49$ & $169(41.9)$ & $1.2(1.08)^{*}$ & $1.7(3 / 169)$ \\
$50-59$ & $154(38.2)$ & $1.5(1.15)$ & $4.5(7 / 154)$ \\
$60-69$ & $17(4.2)$ & $2.3(1.32)$ & $5.8(1 / 17)$ \\
\hline
\end{tabular}

SD: standard deviation. ${ }^{*} \mathrm{p}<0.05$ compared to the highest age group by ANOVA comparing test. 
between the PCA mortality and pesticide use among farmers older between 30 - 49 years living in the area of Rio de Janeiro but the association was low (Odds $=2.68$ ) for the same age group in the area of Porto Alegre [13]. However, there is no doubt that an advanced age is the main risk factor for onset of PCA [14]. The detection rate of PCA before age 50 is very low unless there is a family history of this disease (father, uncle, brother or close to related first degree with PCA) where the risk of developing PCA is very high [15]. The etiology of PCA remains misunderstood. The occurrence of this disease seems to be resulting complex interactions between genetic, hormonal and environmental factors [3]. Through the results of this present study, a PSA screening in men older less than 50 years is unnecessary although early detection of PCA is very important in high-risk groups such as men with a family history of PCA. Aside from the controversy on the validity of PCA screening, urological literature much disputed PCA screening by serumPSA assay in men older less than 50 years [16]. Modern screening strategies are now a risk of over-diagnosis of PCA that's associated with the onset of pain mainly due to unnecessary, annoying and stressful medical treatment. The treatment of symptoms, associated with incontinence and impotence, is a well established fact that no painful.

\section{CONCLUSION}

In our study, there is no recorded position of over-diagnosis and unnecessary and cumbersome treatment for all farmer candidates for serum-TPSA assay but only early detection of prostate cancer by PSA and digital rectal examination is not recommended at this time for men aged less than 50 years.

\section{ACKNOWLEDGEMENTS}

Our thanks go to the Ahmed-Medgheri-hospital in Saida city, all managers, doctors, nurses, technicians and pharmacists working in different departments of internal medicine, urology, occupational medicine, preventive medicine and epidemiology at the hospital in Saida. Our thanks also go to those responsible for the town hall of Saida city, agricultural cooperatives, agricultural chamber and those of NOFC. We thank all farmers who are both candidates and patients in our study, for their full participation in this small research project. We also thank the Algerian associations of cancer for their technical support and recommendations.

\section{REFERENCES}

[1] Hamdi Cherif, M., Zaidi, Z., Abdellouche, D., et al. (2010) Registre du cancer de Sétif (Algérie): Incidence, tendance et survie, 1986-2005. Journal of African Cancer, 3-6.

[2] Baldi, I. and Lebailly, P. (2007) Cancers et pesticides.
Revue du praticien, 57, 40-44.

[3] Blanchet, P. and Multigner, L. (2008) Pesticides et cancer de la prostate. Progrès en Urologie, 18, 19-21.

[4] Tombal, B. (2006) Dosage de l'antigène spécifique prostatique: Quels sont les challenges en 2006? Cliniques Universitaires Saint Luc, Bruxelles.

[5] Tombal, B. (2006) Over and underdiagnosis of prostate cancer. Urology Supplements, 5, 511-516. doi:10.1016/j.eursup.2006.02.019

[6] Klotz, L. (2005) Active surveillance with selective delayed intervention using PSA doubling time for good risk prostate cancer. European Urology, 47, 16-21. doi:10.1016/j.eururo.2004.09.010

[7] Bernier, R. (1998) Dépistage du cancer de la prostate: Utilisation du PSA. Collège des médecins du Québec, $1-5$.

[8] Coley, C.M., Christopher, M., Barry, M.J., Fleming, C., Fahs, M.C. and Mulley, A.G. (1997) Early detection of prostate cancer. Part II: Estimating the risks, benefits, and costs. Annals of Internal Medicine, 126, 468-479. doi:10.7326/0003-4819-126-6-199703150-00010

[9] Conseil d'évaluation des technologies de la santé du Québec (1995) Le dépistage du cancer de la prostate: Evaluation des avantages, des effets indésirables et des couts. le conseil, Aout, Montréal.

[10] Steinberg, G., Carter, B.S., Beaty, T.H., Childs, B. amd Walsh, P.C. (1990) Family history and the risk of prostate cancer. Prostate, 17, 337-347. doi:10.1002/pros.2990170409

[11] Ravery, V. (2002) Les principes d'Utilisation du PSA et de ses dérivés dans la détection du cancer de la prostate. Points d'Actualité, 1, 17-19.

[12] Safi, J.M. (2002) Association between chronic exposure to pesticides and recorded cases of human malignancy in Gaza Governorates (1990-1999). The Science of the Total Environment, 284, 75-84. doi:10.1016/S0048-9697(01)00868-3

[13] Meyer, A., Chrisman, J., Costa Moreira, J. and Koifman, S. (2003) Cancer mortality among agricultural workers from Serrana Region, state of Rio de Janeiro, Brazil. Environmental Research, 93, 264-271. doi:10.1016/S0013-9351(03)00065-3

[14] Bauvin, E., Remontet, L. and Grosclaude, P. (2003) Incidence and mortality of prostate cancer in France: Trends between 1978 and 2000. Progrès en Urologie, 13, 13341339.

[15] Carter, B.S., Beaty, T.H., Steinberg, G.D., Childs, B. and Walsh, P.C. (1992) Mendelian inheritance of familial prostate cancer. Mendelian inheritance of familial prostate cancer. National Academy of Sciences of USA, 89, 33673371

[16] Coulange, C. (2006) Du bon usage du PSA (Antigène spécifique prostatique): Recommandations de l'association Française d'urologie. E-mémoires de l'Académie $\mathrm{Na}$ tionale de Chirurgie, 5, 19-21. 


\section{NOTE LIST OF ABREVIATION}

PCA: Prostate cancer;

PSA: Prostate specific antigen;

NOFC: National office of feed for cattle;

TPSA: Total prostate specific antigen;

VIDAS: Video image digital analysis;

ELFA: Enzyme-linked fluorescent assay;

ELISA: Enzyme linked immunosorbent assay. 